\title{
Antiparasitic activity of Ophiocomina nigra in Entamoeba invadens
}

\section{Actividad antiparasitaria de Ophiocomina nigra en Entamoeba invadens}

\author{
SÁNCHEZ-RAMOS, Sanjuana ${ }^{1} \dagger^{*}$, VALDES-SANTIAGO, Laura ${ }^{2}$, CASTRUITA-DOMÍNGUEZ, José \\ Pedro $^{3}$ and VILLAGÓMEZ-CASTRO, Julio César ${ }^{2}$
}

\author{
${ }^{I}$ Instituto Tecnológico Superior de Irapuato \\ ${ }^{2}$ Universidad de Guadalajara \\ ${ }^{3}$ Universidad de Guanajuato \\ ID $1^{\text {st }}$ Author: Sanjuana, Sánchez-Ramos / ORC ID: 0000-0001-6835-0494 \\ ID $1^{\text {st }}$ Coauthor: Laura, Valdes-Santiago / ORC ID: 0000-0002-2943-7754 \\ ID $2^{\text {nd }}$ Coauthor: José Pedro, Castruita-Domínguez / ORC ID: 0000-0002-3834-1631 \\ ID $3^{\text {rd }}$ Coauthor: Julio César, Villagómez-Castro / ORC ID: 0000-0002-7350-2314
}

DOI: $10.35429 / E J R G .2019 .8 .5 .1 .7$

Received March 12, 2019; Accepted June 30, 2019

\begin{abstract}
Objetive: Analyze the antiparasitic activity of marine invertebrate Ophiocomina nigra in Entamoeba invadens. Methodology. In O. nigra, an analysis of the quantitative proximal chemical composition (moisture, ash, protein, lipids and nitrogen-free extract) was performed. In addition, the determination of the total protein pattern (SDS-PAGE 10\%). On the other hand, the antiparasitic activity of E. invadens trophozoites was determined, which were grown in TYI medium at $28^{\circ} \mathrm{C}$ and exposed to the aqueous extract of $O$. nigra for 24 hours. Subsequently, metabolic activity (XTT assay) was determined and morphology was analyzed. Cytotoxicity tests were performed on human liver cells (Hep G2) exposed for 24 hours to $O$. nigra (XTT test) and the biomass was determined (violet crystal staining). Contribution. The antiparasitic activity of $O$. nigra in $E$. invadens and the cytotoxic effect in human liver cells was determined. There are few scientific studies of this marine invertebrate on its use in traditional medicine, so it is important to analyze its effects and therapeutic value.
\end{abstract}

Ophiocomina nigra, Entamoeba invadens, Trophozoites

\begin{abstract}
Resumen
Objetivo: Analizar la actividad antiparasitaria del invertebrado marino Ophiocomina nigra en Entamoeba invadens. Metodología: En O. nigra, se realizó un análisis de la composición química proximal cuantitativa (humedad, cenizas, proteína, lípidos y extracto libre de nitrógeno). Además, la determinación del patrón total de proteínas (SDS-PAGE 10\%). Por otra parte, se determinó la actividad antiparasitaria de trofozoítos de E. invadens los cuales fueron cultivados en medio TYI a $28^{\circ} \mathrm{C}$ y expuestos al extracto acuoso de $O$. nigra por $24 \mathrm{~h}$. Posteriormente, se determinó la actividad metabólica (ensayo de XTT) y se analizó la morfología. Ensayos de citotoxicidad se realizaron en células hepáticas de humano (Hep G2) expuestas por 24h a O. nigra (ensayo de XTT) y se determino la biomasa (tinción con cristal violeta). Contribución. Se determinó la actividad antiparasitaria de $O$. nigra en $E$. invadens y el efecto citotóxico en células hepáticas humanas. Existen pocos estudios científicos de este invertebrado marino sobre su uso en la medicina tradicional, por lo que es importante analizar sus efectos y el valor terapéutico.
\end{abstract}

Ophiocomina nigra, Entamoeba invadens, Trofozoítos

Citation: SÁNCHEZ-RAMOS, Sanjuana, VALDES-SANTIAGO, Laura, CASTRUITA-DOMÍNGUEZ, José Pedro and VILLAGÓMEZ-CASTRO, Julio César. Antiparasitic activity of Ophiocomina nigra in Entamoeba invadens. 2019, 5-8: 1-7

\footnotetext{
* Correspondence to Author (email: sansanchez@itesi.edu.mx)

$\dagger$ Researcher contributing first author.
} 


\section{Introduction}

The fragile stars (Ophiuroidea) are marine invertebrates belonging to the Equinodermata edge, within this class of the Echinoderms is Ophiocomina nigra, which is a dark colored star, with a round, flat central disk up to $2.5 \mathrm{~cm}$ in diameter. The five thin and flexible arms are approximately five times the diameter of the disc in length (Baharara \& Amini, 2015).

Marine invertebrates have evolved in complex ways, to overcome these challenges they have a defense system that is based on an innate immune system that includes humoral and cellular responses (Nam, et al., 2015), but like all other invertebrates they lack a vertebrate adaptive immune system (Li, Blencke, Haug, \& Stensvåg, 2014). Echinoderm lectins have been attributed the function of agglutinating erythrocytes and inhibiting the adhesion of bacteria. In addition, the presence of antimicrobial peptides (AMP's) which have cytotoxic, antibacterial, antifungal and antiparasitic activity.

The innate immune system of echinoderms also has several antimicrobial components, such as lysozyme (Li, Blencke, Haug, \& Stensvåg, 2014). For all the above, marine invertebrates have been studied during the last years and bioactive molecules with potential therapeutic use have been isolated.

This research aims to analyze the composition of the marine invertebrate $O$. nigra and evaluate its antiparasitic activity in Entamoeba invadens. E. parasdens reptile invadens, has been used as a study model as it presents similarity with Entamoeba histolytica (causative agent of human amebiasis) with respect to its morphology, life cycle, physiology and pathogenesis (Geiman and Ratcliffe., 1936; Mc Connachie, 1995; Diamond et al., 1978).

\section{Material and methods}

\section{Aqueous extract of $O$. nigra}

The dried starfish was obtained from an herbal shop, subsequently its size was measured and pulverized. A stock of aqueous extract was prepared with the powdered sample and to remove undissolved material it was centrifuged at $15294 \mathrm{rcf}$ for $10 \mathrm{~min}$.

\section{Electrophoresis in denaturing conditions $10 \%$}

To obtain the total $O$. nigra proteins, a total homogenate in $2 \%$ SDS was performed in phosphate buffer at $\mathrm{pH} 7.0$ plus a mixture of protease inhibitors (Complete Mini-Roche), then the separation of the proteins in $10 \%$ polyacrylamide gels under denaturing conditions (SDS-PAGE), using the technique described by Laemmli (1970). The gel was stained with silver for protein visualization, image acquisition was performed on a ChemiDoc MP SystemBIORAD using Image LabTM software (BIORAD).

\section{Quantitative proximal chemical composition}

The chemical composition was performed according to Kirk R.S. et al. (nineteen ninety six).

Determination of humidity. The sample (1 g) was placed in an oven (Novatech E145AIA) at $100-105^{\circ} \mathrm{C}$ for $8 \mathrm{~h}$, then it was weighed to determine the $\%$ humidity using the following equation:

$\%$ Humidity = initial sample weight - dry sample weight / initial sample weight x 100

Total dry ash method. The dehydrated sample ( $1 \mathrm{~g}$ ) was calcined in a flask (Terlab MA12D) at $550^{\circ} \mathrm{C}$ for $2 \mathrm{~h}$, then the weight was recorded and determined:

$\%$ Ash on dry basis = ash weight $/$ sample weight $\mathrm{x} 100$

Direct extraction method with organic solvent for lipid determination. The dehydrated sample (1 g) placed in a cellulose thimble was placed in a leach. $110 \mathrm{~mL}$ of petroleum ether were placed in a flat-bottomed ball flask and assembled with a soxhlet and placed in an extraction equipment (Novatech VH-6) at a temperature of $100^{\circ} \mathrm{C}$ adapted to a recirculator (ECO 30) at $7^{\circ} \mathrm{C}$ for $8 \mathrm{~h}$. The condensation rate was 3-6 drops / sec. After extraction, the thimble was removed, the solvent was evaporated from the flasks and placed in an oven (NovatechE145AIA) at $100^{\circ} \mathrm{C}$ for $30 \mathrm{~min}$, cooled in a desiccator and the weight recorded. 

equation:

The determination was made using the

$\%$ Crude fat $=$ weight of the flask with fat weight of the flask / sample weight x 100

Quantification of raw fiber. The sample (1 g) previously dehydrated and degreased was digested with two drops of octyl alcohol and 200 $\mathrm{mL}$ hot $0.255 \mathrm{~N}$ sulfuric acid and boiled for 30 min (Craft FC-600). Subsequently, it was filtered on linen cloth and washed with boiling distilled water, at the end $200 \mathrm{~mL}$ of hot $0.313 \mathrm{~N}$ sodium hydroxide was added and boiled for 30 min. The samples were filtered by suction through a gooch crucible with thin layers of asbestos in the bottom. Finally, they were washed with $15 \mathrm{~mL} 95 \%$ ethyl alcohol and dried at $105^{\circ} \mathrm{C}$ for $12 \mathrm{~h}$ and weighed. Then, they were incinerated at $600{ }^{\circ} \mathrm{C}$ for $1 \mathrm{~h}$ in a flask (Terlab MA12D) and the sample was weighed.

$\%$ Crude fiber $=$ incinerated sample weight / sample weight x 100

Protein Determination The Kjeldahl micrometer (Novatech RJR0549F2) was used, which was based on wet combustion of the sample by heating with concentrated sulfuric acid in the presence of metal catalysts, reducing organic nitrogen to ammonia. The ammonia was titrated with $0.05 \mathrm{~N}$ hydrochloric acid and the protein percentage was calculated by the following equation, using the conversion factor (6.25) of nitrogen to protein.

$\%$ Protein $=(\mathrm{mL} \mathrm{HCl})(\mathrm{N})(0.01401)$ (Factor $)$ (100) / g sample

Determination of the nitrogen free extract (ELN). It was determined with the equation:

$\% \mathrm{ELN}=100 \%-[(\%$ ash $)+(\%$ protein $)+(\%$ lipids $)+(\%$ fiber $)]$

\section{Cultivation of Entamoeba invadens and liver cells and exposure to $O$. nigra}

The maintenance of $\mathrm{E}$. invadens trophozoites was performed in TYI-S-33 medium at $28^{\circ} \mathrm{C}$. HepG2 human liver cells (ATCC® HB-8065 TM) were cultured in DMEM medium supplemented with $10 \%$ fetal bovine serum and maintained at $37^{\circ} \mathrm{C}$ with an atmosphere of 5\% CO2. The cell line was manipulated with the type 1 biosafety level requirements to which it corresponds.
The amoebas or liver cells were exposed to the aqueous extract of $\mathrm{O}$ nigra for 24 hours at different concentrations: $31.25,62.5,125,250$ and $500 \mathrm{mg} / \mathrm{mL}$, at the end of the incubation time the mitochondrial metabolic activity and biomass were determined.

\section{Mitochondrial metabolic activity}

XTT (2,3-bis (2-methoxy-4-nitro-5sulfophenyl) -2-h-tetrazolium-5-carboxanilide) was added to the amoebas or liver cells exposed to $O$. nigra at a concentration of $0.25 \mathrm{mg} / \mathrm{mL}$ in Menadiona (Sigma) at $0.1 \mathrm{mM}$ and will be incubated for $90 \mathrm{~min}$ at $37^{\circ} \mathrm{C}$ in the dark. The reduction of salt to water-soluble formazan crystals, a biochemical process performed by mitochondrial dehydrogenases of viable cells, will be measured at $490 \mathrm{~nm}$ in a microplate spectrophotometer (Epoch TM BioTek).

\section{Biomass Determination}

Samples were fixed with $99 \%$ methanol for 15 min at room temperature. The methanol was washed with PBS (Phosphate buffer solution $\mathrm{pH}$ 7.2 ) and the $0.001 \%$ violet crystal was added for 5 min. Staining with the violet crystal allowed the interaction of the cationic dye with the negatively charged cell components. Subsequently, 33\% acetic acid was added for 10 min for dye dissolution. The absorbance at 570 $\mathrm{nm}$ was measured at a recovered supernatant in a microplate spectrometer (Epoch TM Biotek).

\section{Results}

Ophiocomina nigra is a marine star with thin and flexible arms, its coloration is homogeneous from dark brown to black; It is a species of marine invertebrate and dry specimens of an average size of $20 \mathrm{~cm}$ used in this study were purchased from a herbalist's shop (Fig. 1).

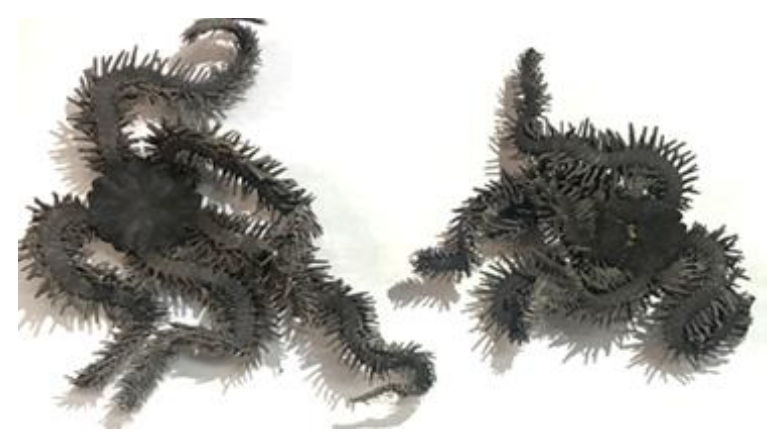

Figure 1 Ophiocomina nigra 
O. nigra has been used in traditional medicine by oral consumption, previously pulverized and added to food. Therefore, a bromatological analysis was performed observing that the proximal chemical composition that makes up this organism corresponds to $7.8 \%$ proteins, $4.2 \%$ lipids, $2.57 \%$ crude fiber, $1.2 \%$ nitrogen free extract (ELN), $82.25 \%$ ashes and moisture $1.59 \%$ (Fig. 2).

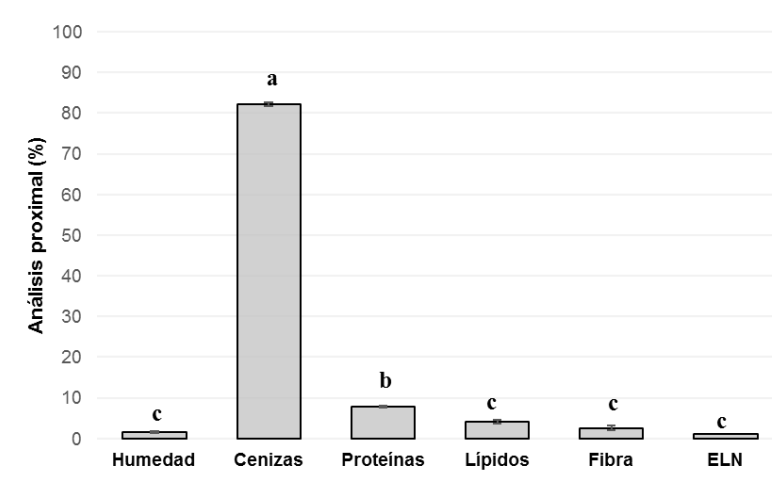

Figure 2 Proximal chemical composition of $O$. nigra

At the different parameters a comparison of means $(n=3)$ was performed by the Tukey method $(* p \leq 0.05)$, the different letters indicate a significant difference. ELN, nitrogen free extract.

The analysis of the total protein profile of $O$. nigra indicates a wide range of proteins with a $\mathrm{Mr} \geq 200-16 \mathrm{kDa}$ (Fig. 3), where it can be observed that there are some proteins with greater intensity.

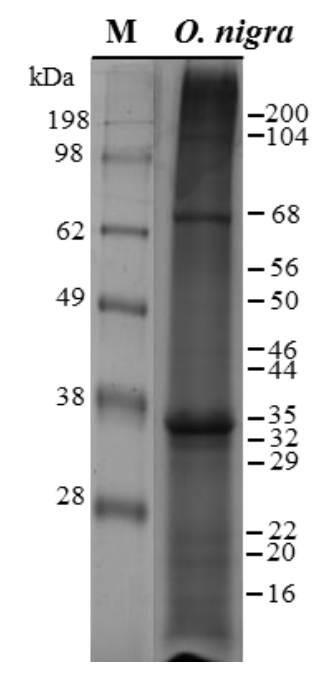

Figure 3 Total $O$. nigra proteins
The antiparasitic activity attributed to $O$. nigra was tested using E. invadens as an in vitro model. Therefore, E. invadens trophozoites were exposed with the aqueous extract of $O$. nigra, observing that the antiparasitic activity was $50.29 \%$ at the concentration of $31.25 \mathrm{mg} / \mathrm{mL}$. In contrast, it was observed that at a higher concentration of $O$. nigra the antiparasitic activity was less than $27 \%$ (Fig. 4), however, it should be mentioned that from the concentration of $62.5 \mathrm{mg} / \mathrm{mL}$ a cellular damage was observed therefore a change in the morphology of the trophozoite, loss of adhesion and cellular debris (Fig. 5A). It is suggested that the damage caused to trophozoites caused the release of reducing agents of $\mathrm{E}$. invadens and as a consequence the increase in the determination of metabolic activity was observed, a method based on the reduction of XTT to formazan (Fig. 5B).

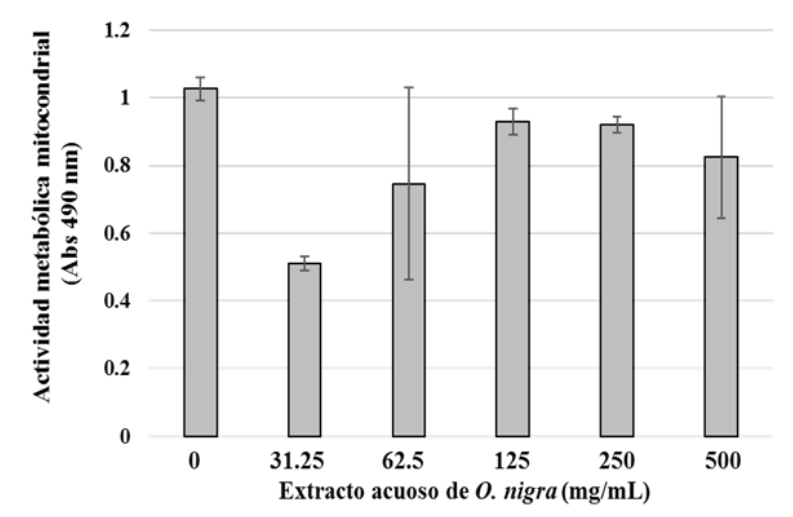

Figure 4 Determination of the antiparasitic activity of $O$. nigra in trophozoites of E. invadens
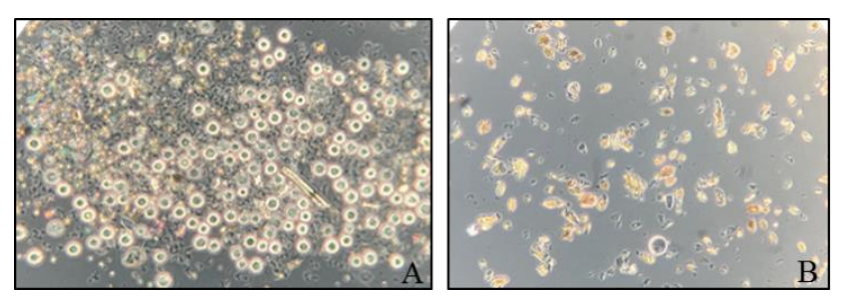

Figure 5 Morphology of E. invadens after $24 \mathrm{~h}$ of exposure with the aqueous extract of $O$. nigra

A. The loss of the cell monolayer, the formation of trophozoite clusters, cell debris and loss of morphology (A) are observed, later when washing with phosphate buffer solution $(\mathrm{pH}$ 7.2 ), the $\mathrm{O}$ fragments are observed nigra and some trophozoites at the bottom of the culture plate (B). 20X 
On the other hand, the cytotoxic activity of the aqueous extract of $O$. nigra was determined in a culture of human liver cells, observing that regardless of the concentration of $O$. nigra, the mitochondrial metabolic activity was higher than the liver cells that were not exposed ( Fig. 6), due to cell damage and the release of reducing compounds. This cellular damage was also observed when analyzing the decrease in biomass dependent on the concentration of $O$. nigra; at the highest concentration $(500 \mathrm{mg} / \mathrm{mL})$ a $59.26 \%$ loss of biomass was obtained, indicating the loss of adhesion and cell junctions, therefore, the lack of maintenance of the cell monolayer (Fig. 7) . These results indicate a cytotoxic effect caused by $O$. nigra in liver cells.

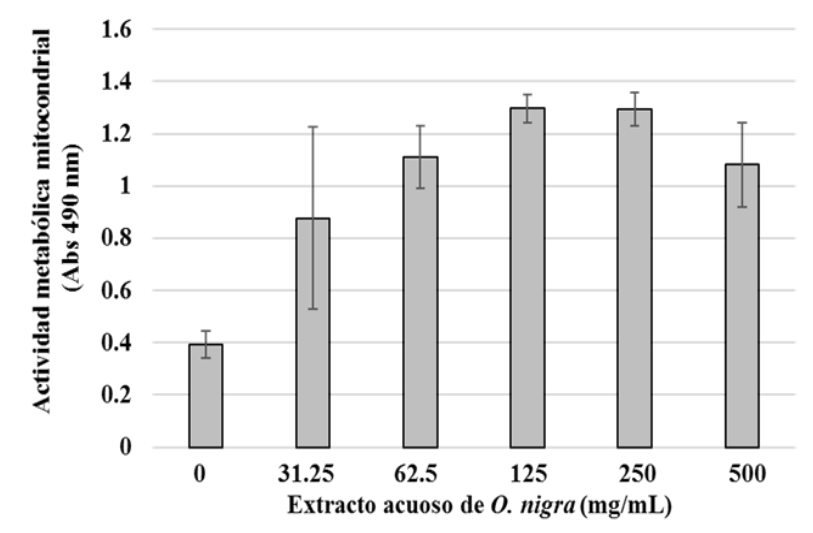

Figure 6 Determination of the cytotoxic activity of $O$. nigra in human liver cells

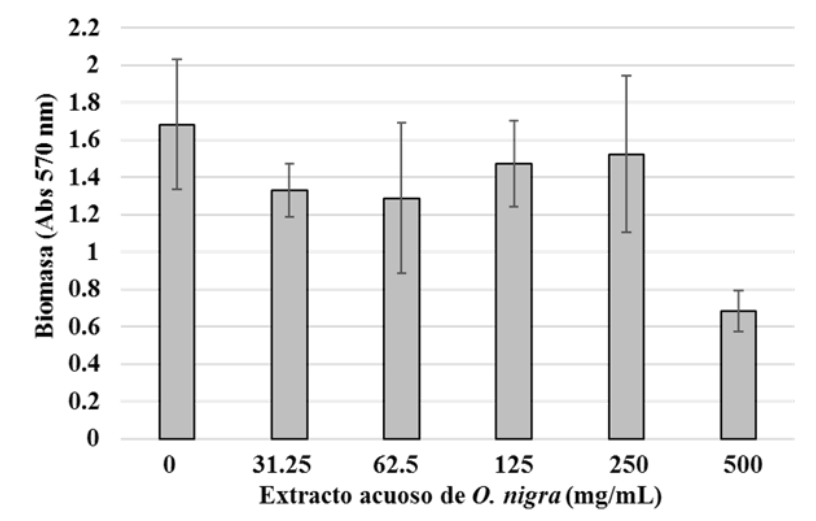

Figure 7 Biomass of liver cells exposed to O. nigra

\section{Discussion}

In traditional medicine, echinoderms such as Oreaster reticulate, Echinaster echinophorus, Luidia senegalensis, Mellita quinquiesperforata, Echinometra lucunter and Echinaster brasiliensis are used in Brazil against asthma, alcoholism, bronchitis, diabetes and heart disease.
This therapeutic potential is due to the ethnopharmacological information of natural products (Marmouzi, et al., 2017). The route of administration reported is oral, by preparing an infusion or direct addition to powdered roasted echinoderm foods. In this sense, it was relevant to perform an analysis of the proximal chemical composition which indicated a higher percentage of proteins (7.8\%) compared to lipids, crude fiber and nitrogen free extract.

In traditional medicine, echinoderms such as On the other hand, there are the presence of some bioactive substances in fragile stars and it has been shown that they can play an important role in cancer therapy (Baharara \& Amini, 2015), another invertebrate with activity Antitumor is the sea cucumber Holothuria nobilis attributing a more potent anticancer activity compared to drugs used in the treatment of cancer such as Taxol, Etoposide and Ara-C (Layson, Rodil, Mojica, \& Deocaris, 2014).

In $O$. nigra, the anticoagulant activity of acid mucopolysaccharides in the mucous secretions has been demonstrated, in addition to the glycoproteins present in the secretion and the cell surface it has been reported to inhibit the adhesion of human neutrophils to endothelial cells, proposing a mechanism of Competitive inhibition of this interaction Oreaster reticulate, Echinaster echinophorus, Luidia senegalensis, Mellita quinquiesperforata, Echinometra lucunter and Echinaster brasiliensis are used in Brazil against asthma, alcoholism, bronchitis, diabetes and heart disease.

This therapeutic potential is due to the ethnopharmacological information of natural products (Marmouzi, et al., 2017). The route of administration reported is oral, by preparing an infusion or direct addition to powdered roasted echinoderm foods. In this sense, it was relevant to perform an analysis of the proximal chemical composition which indicated a higher percentage of proteins (7.8\%) compared to lipids, crude fiber and nitrogen free extract. In this study, exposure of liver cells to $O$. nigra indicated a cytotoxic effect, although it should be noted that a total aqueous extract of $O$. nigra was used, where other bioactive molecules of this echinoderm were probably present. In the case of inhibition of the adhesion of bacteria to the substrate, the formation of large aggregates has been observed suggesting adhesion to the $O$. nigra glycoprotein molecule (Bavington $\mathrm{C}$. et al., 2004).

SÁNCHEZ-RAMOS, Sanjuana, VALDES-SANTIAGO, Laura, CASTRUITA-DOMÍNGUEZ, José Pedro and VILLAGÓMEZCASTRO, Julio César. Antiparasitic activity of Ophiocomina nigra in Entamoeba invadens. 2019 
Similar results were obtained in the E. invadens exposure test to $O$. nigra, where trophozoite aggregates and loss of substrate adhesion were observed. Various bioactive molecules have been isolated from marine invertebrates, such as glycoside steroids consisting of saponins, cyclic steroidal glycosides, monoglycosides and steroidal diglycosides (Sumithaa, Banu, \& Parvathi, 2017), terpenes, sulfated sterols, carotnoid sulfate, phenylpropaides , naphthoquinones, (Baharara \& Amini, 2015), ketones and aldehydes (Thao, et al., 2014) and AMP's (Li, Blencke, Haug, \& Stensvåg, 2014). In the case of saponins, it is considered one of the main constituents of some herbal drugs, research related to its existence in the marine environment has been attractive to scientists (Amini, Nabiuni, Baharara, Parivar, \& Asili, 2014 ). Thanks to this interest, a steroidal saponin called ophiurosaponin has been identified in Ophiopholis mirabilis extracts (Wnag, Xue, Zhen, \& Guo, 2014). Therefore, the use of bioactive molecules of echinoderms with a therapeutic value is attractive.

\section{Conclusion}

The antiparasitic activity of $O$. nigra was determined in E. invadens and a cytotoxic effect in human liver cells.

\section{References}

Amini, E., Nabiuni, M., Baharara, J., Parivar, K., \& Asili, J. (2014). Hemolytic and cytotoxic effects of saponin like compounds isolated from Persian Gulf brittle star (Ophiocoma erinaceus). Journal of Coastal Life Medicine, 2 (8), 614-620.

Avant, P. (2008). Ophiocomina nigra Black brittlestar. Recuperado el 2018, de The Marine Biological Association of the United Kingdom: https://www.marlin.ac.uk/species/detail/1706

Baharara, J., \& Amini, E. (2015). The Potential of Brittle Star Extracted Polysaccharide in Promoting Apoptosis via Intrinsic Signaling Pathway. Avicenna Journal of Medical Biotechnology, 7 (4), 151-158.

Balakrishnan, D., Bibiana, A. S., Vijayakumar, A., Santhosh, R. S., Dhevendaran, K., \& Nithyanand, P. (2015). Antioxidant Activity of Bacteria Associated with the Marine Sponge Bavington CD, Lever R, Mulloy B, Grundy MM, Page CP, Richardson NV, McKenzie JD.
2004 Anti-adhesive glycoproteins in echinoderm mucus secretions. Comp Biochem Physiol B Biochem Mol Biol. 2004, 139(4): 607-617

Bavington CD, Lever R, Mulloy B, Grundy MM, Page CP, Richardson NV, McKenzie JD. 2004 Anti-adhesive glycoproteins in echinoderm mucus secretions. Comp Biochem Physiol B Biochem Mol Biol. 2004, 139(4): 607-617

Kim, C.-H., Go, H.-J., Oh, H. Y., Park, J. B., Lee, T. K., Seo, J.-K., y otros. (2018). Identification of a novel antimicrobial peptide from the sea star Patiria pectinifera. Developmental and Comparative Immunology, 86, 203-213.

Kiran, N., Siddiqui, G., Khan, A. N., Ibrar, K., \& Tushar, P. (2014). Extraction and Screening of Bioactive Compounds with Antimicrobial Properties from Selected Species of Mollusk and Crustacean. Journal of Clinical \& Cellular Immunology, 5 (1).

KIRK R.S., Sawyer, R y Egan H. "Composición y Análisis de Alimentos de Pearson”. Segunda edición. Editorial CECSA. México 1996.

KIRK R.S., Sawyer, R y Egan H. "Composición y Análisis de Alimentos de Pearson". Segunda edición. Editorial CECSA. México 1996.

Layson, R. J., Rodil, M. C., Mojica, E.-R. E., \& Deocaris, C. C. (2014). Potential Anti-cancer and Anti-bacterial Activities of Philippine Echinoderm Extracts. The Journal of Tropical Life Science, 4 (3), 175-181.

Li, C., Blencke, H.-M., Haug, T., \& Stensvåg, K. (2014). Antimicrobial peptides in echinoderm host defense. Developmental and Comparative Immunology, 49 (1), 190-197.

Marmouzi, I., Tamsouri, N., Hamdani, M. E., Attar, A., Kharbach, M., Alami, R., y otros. (2017). Pharmacological and chemical properties of some marine echinoderms. Brazilian Jorunal of Pharmacognosy .

Nam, B.-H., Seo, J.-K., Lee, M. J., Kim, Y.-O., Kim, D.-G., An, C. M., y otros. (2015). Functional analysis of Pacific oyster (Crassostrea gigas) b-thymosin: Focus on antimicrobial activity. Fish \& Sellfish Immunology, 45, 167-174.

Sumithaa, R., Banu, N., \& Parvathi, D. V. (2017). Novel Natural Products from Marine Sea SÁNCHEZ-RAMOS, Sanjuana, VALDES-SANTIAGO, Laura, CASTRUITA-DOMÍNGUEZ, José Pedro and VILLAGÓMEZCASTRO, Julio César. Antiparasitic activity of Ophiocomina nigra in Entamoeba invadens. 2019 
Stars. Current Trends in Biomedical Engineering \& Biosciences, 2 (24).

Vergara, W., \& Rodríguez, A. (2016). Nutritional Composition of Sea Cucumber Isostichopus sp. Natural Resources, 7, 130-137. Wnag, R., Xue, X., Zhen, J., \& Guo, C. (2014). Antioxidant and Antimicrobial Activity of Ophiurasaponin Extracted from Ophiopholis mirabilis. Journal of Chemistry. 